\title{
Novel cycloartane triterpenoid from Cimicifuga foetida (Sheng ma) induces mitochondrial apoptosis via inhibiting Raf/ MEK/ERK pathway and Akt phosphorylation in human breast carcinoma MCF-7 cells
}

Hai-yan Sun ${ }^{1,2}$, Bei-bei Liu, Jian-yang Hu ${ }^{3}$, Li-jia Xu', Shun-wan Chan², Chi-on Chan², Daniel K. W. Mok², Dong-mei Zhang ${ }^{3 *}$, Wen-cai Ye ${ }^{3}$ and Si-bao Chen ${ }^{1,2^{*}}$

\begin{abstract}
Background: Cycloartane triterpenoids exhibited anticancer effects. This study aims to identify any potential novel anticancer cycloartane triterpenoids from Cimicifuga foetida L. rhizome (Sheng ma) and the mode of actions.

Methods: Cycloartane triterpenoids were isolated from the C. foetida rhizome by a series of column chromatography and identified by IR, MS and NMR. Their anticancer effects on several human cancer cell lines, MCF-7, HepG2, HepG2/ ADM, HeLa, and PC3, and normal human mammary epithelial cells MCF10A were investigated by colony formation and MTT assays. Morphological analysis of apoptosis induction was performed by acridine orange/ethidium bromide dual-staining and Hoechst 33258 nuclear staining. The cell-cycle profile and annexin V staining were evaluated by flow cytometry. Apoptosis were investigated by measuring changes in mitochondrial membrane potential and analyzing expression of cell cycle- and apoptosis-related proteins in MCF-7 cells by Western blotting.

Results: A novel cycloartane triterpenoid, 25-O-acetyl-7,8-didehydrocimigenol-3-O- $\beta$-D-(2-acetyl)xylopyranoside (ADHC-AXpn), together with the known 7,8-didehydrocimigenol-3-O- $\beta$-D-Xylopyranoside (DHC-Xpn) were isolated. MCF-7 growth was significantly inhibited by ADHC-AXpn in a dose- and time-dependent manner $\left(\mathrm{IC}_{50}: 27.81 \mu \mathrm{M}\right.$ at $48 \mathrm{~h} ; P=0.004 \mathrm{vs}$. control at $25 \mu \mathrm{M}$ for $48 \mathrm{~h}$ treatment), and ADHC-AXpn was selectively cytotoxic for cancerous cells (MCF-7, HepG2/ADM, HepG2 and HELA cells) based on its higher IC $C_{50}$ values for normal cells MCF10A (IC $50: 78.63 \mu \mathrm{M}$ at $48 \mathrm{~h}$ ) than for tumor cells. In MCF-7 cells, ADHC-AXpn induced $\mathrm{G}_{2} / \mathrm{M}$ cell cycle arrest by mediating cyclin-B1, and CDK1 and its phosphorylation; and induced apoptosis through the mitochondrial-mediated apoptotic pathway, with inhibition of Akt activation. As ADHC-AXpn suppressed phosphorylation of ERK1/2, Raf and Akt proteins in MCF-7 cells, its apoptotic effect might be associated with Raf/MEK/ERK signaling and Akt activation.
\end{abstract}

Conclusions: ADHC-AXpn significantly suppressed the growth of MCF-7 cells, induced mitochondrial apoptosis and cell-cycle arrest, and inhibited Raf/MEK/ERK signaling pathway and Akt phosphorylation.

\footnotetext{
*Correspondence: dmzhang701@foxmail.com; sibao.chen@polyu.edu.hk

2 State Key Laboratory of Chinese Medicine and Molecular Pharmacology, Hong Kong Polytechnic University, Hong Kong, China

${ }^{3}$ College of Pharmacy, Jinan University, Guangzhou, China

Full list of author information is available at the end of the article
} 


\section{Background}

Chinese medicine $(\mathrm{CM})$ is a rich source for the development of anticancer drugs and chemopreventive agents [1]. Cycloartane triterpenoid (CATP) are triterpene glycosides with a unique structural C-19 angular methyl (Fig. 1), are distributed in plants of several genuses, such as Astragalus, Cimicifuga, and Thalictrum [2, 3]. Several CATPs isolated from plants exhibited potential anticancer activities [4-7].

The rhizome of Cimicifuga foetida L. (Sheng ma), has been used as an anti-inflammatory, analgesic, and antipyretic agent in CM [8]. C. foetida contains many CATPs $[9,10]$, and some CATPs from the Cimicifuga genus possessed anti-cancer effects in vivo and in vitro [4-6]. However, previous research focused on isolation and structure identification rather than biological activity. Our earlier research associated CATP anticancer activity with apoptosis induction and cell cycle arrest in tumor cells $[4,5]$, but respective biological pathways have not yet investigated.

This study aims to identify any potential novel anticancer CATP from C. foetida and evaluate their effects on the growth, colony formation, apoptosis induction and respective pathways in cancer cells.

\section{Methods}

\section{Plant materials}

Rhizome of C. foetida was collected in Emei Mountain, Sichuan province, China in October 2012 and identified by Dr. Sibao Chen by comparing its morphological features [8]. A voucher specimen (SZRI20121045) was deposited in the herbarium of state key laboratory of Chinese medicine and molecular pharmacology.

\section{Equipment}

Infrared spectra (IR) were recorded on a Shimadzu IR-450 spectrometer (Shimadzu, Kyoto, Japan). High

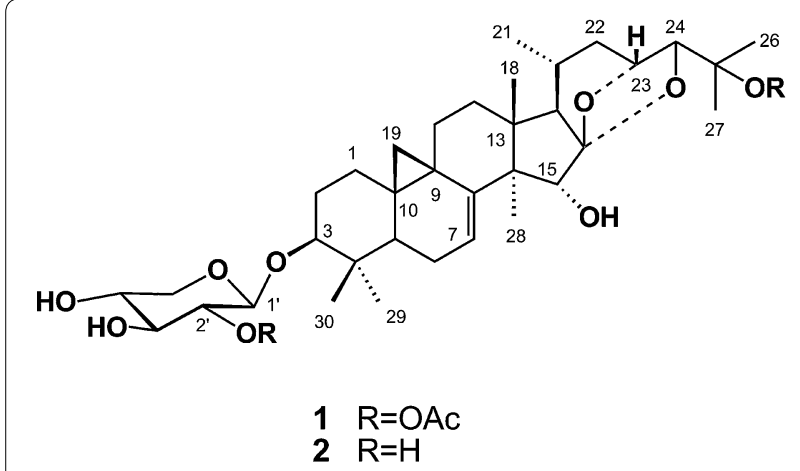

Fig. 1 Chemical structures of components ADHC-AXpn and DHCXpn resolution fast atom bombardment mass spectra (HRFAB-MS) were recorded on a VG-Autospec-3000 spectrometer (Micromass, Manchester, UK), in $\mathrm{m} / \mathrm{z}$ (percentage relative intensity of base peak). The nuclear magnetic resonance (NMR) spectra were measured in pyridine- $d_{5}$ on a Bruker AM-400 spectrometer (BrukerDaltonics, MA, USA), using tetramethyl silane as internal standard. Silica gel- ${ }_{60 \mathrm{H}}(100-200$ and $200-300$ mesh) and silica gel $\mathrm{GF}_{254}$ sheets $(0.20-0.25 \mathrm{~mm}$; both from Qingdao Haiyang Chemical Group Co., Qingdao, China) were used for column chromatography (CCG) and thin layer chromatography (TLC), respectively.

\section{Materials and reagents for pharmacological investigations} 3-(4, 5)-Dimethylthiazol-2-yl)-2, 5-diphenyl tetrazolium bromide (MTT), Hoechst 33258, propidium iodide (PI), doxorubicin (Dox) and carbonyl cyanide 3-c hlorophenylhydrazone were purchased from Sigma-Aldrich (St. Louis, MO, USA). 5, 5', 6, 6'-tetrachloro-1, 1', 3, $3^{\prime}$-tetraethyl benzimidazolyl-carbocyanine iodide (JC1) and Alexa Fluor ${ }^{\circledR} 488$ Annexin V/dead cell apoptosis kit were obtained from invitrogen (Carlsbad, CA, USA). BCA protein assay kit and electro chemiluminescence were obtained from Thermo Fisher Scientific (Rockford, IL, USA). Antibodies against cyclin B1, CDK1, p-CDK1 $\left(\right.$ Thr $\left.^{161}\right)$, caspase-9, cleaved caspase-9, PARP, cleaved PARP, Akt, p-Akt $\left(\mathrm{Thr}^{308}\right.$ and $\mathrm{Ser}^{473}$ ), p-ERK1/2 and p-c-Raf were from cell signaling technology (Beverly, MA, USA). Antibodies against Bcl-2 and Bax were bought from Santa Cruz Biotechnology (Santa Cruz, CA, USA). Protease inhibitor cocktail tablets and phosphatase inhibitor cocktail tablets were supplied by Roche (Roche Applied Science, Mannheim, Germany). Dimethylsulfoxide (DMSO); RPMI-1640 and Dulbecco's modification of Eagle's medium (DMEM), phosphate-buffered saline (PBS), fetal bovine serum (FBS), penicillin-streptomycin $(\mathrm{P} / \mathrm{S})$ and trypsin-ethylene diamine tetraacetic acid (EDTA) were purchased from life technologies (Grand Island, NY, USA).

\section{Extraction and isolation}

The rhizome of C. foetida $(0.5 \mathrm{~kg})$ was extracted three times with $95 \% \mathrm{EtOH}$ for $1 \mathrm{~h}$ under reflux. After combination of extractions and solvent removal, the residue $(129 \mathrm{~g})$ was suspended in water $(1 \mathrm{~L})$ and partitioned successively with $200 \mathrm{~mL}$ each of petroleum ether (60$80{ }^{\circ} \mathrm{C}$ ), ethyl acetate and $\mathrm{n}-\mathrm{BuOH}$. The ethyl acetate fraction $(28 \mathrm{~g})$ was subjected to CCG on silica gel $^{-} 60 \mathrm{H}$ (100-200 mesh). Gradient elution with $\mathrm{CHCl}_{3}-\mathrm{MeOH}$ (1:0, 50:1, 20:1, 10:1 and 0:1), obtained five fractions: A (3.7 g), B (4.9 g), C (6.28 g), D (1.5 g) and E (1.8 g).

Fraction D was subjected to CCG on silica gel- ${ }_{60 \mathrm{H}}$ (200-300 mesh), eluted with $\mathrm{CHCl}_{3}-\mathrm{MeOH}$ (70:30) 
and further purified by Sephadex $G_{10}$ CCG, eluted with $\mathrm{MeOH}$ to obtain ADHC-AXpn (15 mg).

Fraction $\mathrm{C}$ was subjected to repeated CCG on silica gel $_{60 \mathrm{H}}$ (200-300 mesh), eluted with $\mathrm{CHCl}_{3}$ and acetone (3:1) to give sub-fractions $1-5$. Sub-fraction 5 was subjected to CCG on silica gel- ${ }_{60 \mathrm{H}}$ (200-300 mesh), eluted in gradient with $\mathrm{CHCl}_{3}-\mathrm{MeOH}$ (90:10, 85:15 and 80:20). The fraction eluted by $\mathrm{CHCl}_{3}-\mathrm{MeOH}$ (80:20) was purified by Sephadex $\mathrm{G}_{10} \mathrm{CCG}$, and eluted with $\mathrm{MeOH}$, to give DHC-Xpn (40 mg). Chemical structures of ADHCAXpn and DHC-Xpn were elucidated by their spectral data (IR, MS and ${ }^{1} \mathrm{H},{ }^{13} \mathrm{C}-\mathrm{NMR}$ ) and by comparison with data in the literature. The purity of isolated components was determined over $98 \%$ by peak area normalization method in HPLC analysis by an Agilent 1200 liquid chromatography system (HP Agilent Technologies, Palo Alto, CA, USA).

\section{Cell culture}

Cell lines MCF-7 (estrogen receptor-positive phenotype), HepG2, HeLa and PC3 cells were obtained from American type culture collection (Manassas, VA, USA). HepG2/ ADM cells (multidrug resistance phenotype) were kindly provided by Prof. Kwok-Pui Fung (The Chinese University of Hong Kong, Hong Kong, China). Human MCF10A mammary epithelial cells were obtained from Invitrogen (Carlsbad, CA, USA). The MCF-7, HepG2, HepG2/ADM and PC3 cells were cultured in RPMI-1640 medium supplemented with $10 \mathrm{FBS}$ and $1 \%(\mathrm{v} / \mathrm{v}) \mathrm{P} / \mathrm{S}$ at $37{ }^{\circ} \mathrm{C}$ in a humidified incubator containing $5 \% \mathrm{CO}_{2}$. HeLa cells were cultured in DMEM medium with the same culture condition mentioned above. Human MCF10A mammary epithelial cells were cultured in a condition mentioned previously [11]. HepG2/ADM cells were cultured with $1.2 \mu \mathrm{M}$ of Dox; during cell passage to keep their multidrug resistance property as compared with the corresponding parental cells.

\section{Cell viability assay}

The inhibitory effects of ADHC-AXpn and DHC-Xpn on the growth of tested cells were evaluated by MTT assay. Briefly, all tested cells $\left(0.8 \times 10^{4} /\right.$ well $)$ were seeded in 96-well plates, cultured for $24 \mathrm{~h}$, then exposed to different concentrations of ADHC-AXpn and DHC-Xpn, respectively for another 24 or $48 \mathrm{~h}$. Subsequently, $30 \mu \mathrm{L}$ of $5 \mathrm{mg} / \mathrm{mL}$ MTT dissolved in PBS was added to each well and incubated for $4 \mathrm{~h}$ after removing the media. Formazan crystals were dissolved with $100 \mu \mathrm{L}$ of DMSO, with absorbance at $490 \mathrm{~nm}$ measured by Bio-Rad 680 microplate reader (Bio-Rad, CA, USA). Cell viability was determined as a percentage of the control, with Dox as positive control.

\section{Colony formation assay}

MCF-7 cells $\left(2.5 \times 10^{5} /\right.$ well $)$ were seeded in 6-well plates, cultured for $24 \mathrm{~h}$, then exposed to different concentrations of ADHC-AXpn (20, 30 or $35 \mu \mathrm{M})$ for $48 \mathrm{~h}$ before digestion in $0.25 \%$ trypsin to reconstitute single-cell suspensions. Cell suspensions were then transferred into 6-well plates $\left(600\right.$ cells/well) and incubated at $37{ }^{\circ} \mathrm{C}$ for 12 days. The formed colonies were fixed in $4 \%$ paraformaldehyde for $30 \mathrm{~min}$ and stained with $1 \%$ crystal violet for $5 \mathrm{~min}$. These experiments were performed three times. Colonies with diameters larger than $0.5 \mathrm{~mm}$ were counted to calculate the colony formation rate.

\section{Hoechst 33258 staining assay}

The nuclear morphology of cells treated with ADHCAXpn was observed with a Hoechst 33258 staining assay. MCF-7 cells $\left(2.5 \times 10^{5} /\right.$ well $)$ were seeded in 6-well plates, cultured for $24 \mathrm{~h}$, and treated with different concentrations of ADHC-AXpn $(20,30$ or $35 \mu \mathrm{M})$ for $48 \mathrm{~h}$. The cells were then washed three times with PBS, fixed in $4 \%$ paraformaldehyde at $4{ }^{\circ} \mathrm{C}$ for $30 \mathrm{~min}$, and stained with $10 \mu \mathrm{g} / \mathrm{mL}$ of Hoechst 33258 for $15 \mathrm{~min}$ at $37{ }^{\circ} \mathrm{C}$. Changes in nuclear morphology were monitored with an Olympus IX51 inverted microscope (Olympus Corporation of the Americas, Inc., Central Valley, PA, USA).

\section{Cell cycle analysis}

Cell cycle distribution was analyzed by a fluorescent probe propidium iodide (PI) staining assay. MCF-7 cells $\left(2.5 \times 10^{5} /\right.$ well $)$ were seeded in 6-well plates, cultured for $24 \mathrm{~h}$, then treated with different concentrations of ADHC-AXpn $(20,30$ or $35 \mu \mathrm{M})$ for 24 or $48 \mathrm{~h}$. Cells were then collected and fixed with $75 \%$ ethanol at $4{ }^{\circ} \mathrm{C}$ overnight. After centrifugation in an Eppendorf 5417R centrifuge (Eppendorf Corp., Hamburg, Germany) at $800 \mathrm{~g}$ for $5 \mathrm{~min}$, the cells were incubated with PBS containing $0.02 \mathrm{mg} / \mathrm{mL}$ PI and $0.1 \mathrm{mg} / \mathrm{mL}$ RNase A in darkness at $37{ }^{\circ} \mathrm{C}$ for $30 \mathrm{~min}$. The emitting fluorescence was measured by Guava Easy Cytometer (Guava Technologies, Millipore, Billerica, MA, USA); data were analyzed with MultiCycle AV software (Phoenix Flow Systems, San Diego, CA, USA).

\section{Annexin V-FITC/PI double staining assay for apoptosis}

MCF-7 cells $\left(2.5 \times 10^{5} /\right.$ well $)$ were seeded in 6-well plates, cultured for $24 \mathrm{~h}$, and exposed to differing concentrations of ADHC-AXpn $(20,30$ or $35 \mu \mathrm{M})$ for $36 \mathrm{~h}$. Cells were then collected and stained by Alexa Fluor ${ }^{\circledR} 488$ Annexin $\mathrm{V} /$ dead cell apoptosis kit according to manufacturer instructions. Green fluorescence emitted from Annexin V-FITC and red fluorescence from PI were detected by Guava Easy Cytometer (Guava Technologies, Millipore, 
Billerica, MA, USA). Data were analyzed by FlowJo 7.6 software (TreeStar, SanCarlos, CA, USA).

\section{Measurement of mitochondrial membrane potential (MMP)}

Changes in MMP were measured using a lipophilic cationic fluorescent probe JC-1. Briefly, MCF-7 cells $\left(2.5 \times 10^{5} /\right.$ well $)$ were seeded in 6-well plates, cultured for $24 \mathrm{~h}$, then treated with ADHC-AXpn $(20,30$ or $35 \mu \mathrm{M})$ for $24 \mathrm{~h}$. The cells were collected and incubated with $5 \mu \mathrm{M} \mathrm{JC}-1$ in darkness at $37{ }^{\circ} \mathrm{C}$ for $15 \mathrm{~min}$, then assayed with a Guava Easy Cytometer (EasyCyte $8 \mathrm{HT}$, Millipore, USA) to evaluate changes in MMP..

\section{Western blotting assay}

MCF-7 cells $\left(2.5 \times 10^{5} /\right.$ well $)$ were seeded in $100-\mathrm{mm}$ culture dishes, cultured for $24 \mathrm{~h}$, then incubated with differing concentrations of ADHC-AXpn for various times. Cells were then collected by trypsinization with $0.25 \%$ Trypsin-EDTA and transferred to centrifuge tubes. After centrifugation at $800 \mathrm{~g}$ for $5 \mathrm{~min}$, cells were washed twice with ice-cold PBS and then lysed in RIPA buffer containing 0.5 M DTT, 0.1 M PMSF and $20 \times$ phosphatase inhibitor for $30 \mathrm{~min}$ on ice. Protein samples were harvested by centrifugation at $12,000 \mathrm{~g}$ at $4{ }^{\circ} \mathrm{C}$ for $12 \mathrm{~min}$. Protein contents were quantified with BCA Protein Assay Kit (Thermo Scientific Pierce, Rockford, USA). The protein samples $(35 \mu \mathrm{g})$ along with a rainbow-colored protein molecular marker (Amersham, Buckinghamshire, UK) were separated by $10 \%$ SDS-PAGE and transferred to polyvinylidene fluoride (PVDF) membranes (Millipore, Bedford, MA, USA) by a semi-dry transfer apparatus (Bio-Rad, CA, USA). The membranes were blocked with $5 \%$ nonfat dry milk in Tris-buffered saline containing $0.1 \%$ Tween-20 (TBS-T) at room temperature for $1 \mathrm{~h}$ and incubated overnight with primary antibodies containing $5 \% \mathrm{BSA}$ at $4{ }^{\circ} \mathrm{C}$. Membranes were washed with TBS-T three times and appropriate secondary antibodies conjugated with horseradish peroxidase were added and incubated for another hour. Finally, immunoblots were visualized by enhanced chemiluminescence detection reagents, with $\beta$-actin as a loading control.

\section{Statistical analysis}

Each experiment was performed for three times and data were presented as mean \pm standard deviation (SD). Analysis of variance (ANOVA) was performed to detect significant differences. In multiple comparisons, Tukey post-test was used. $P$ value less than 0.05 was considered statistically significant. Analyses of dose-, concentration- and time-dependent effects were performed by sigmoidal non-linear regression. All statistical analysis tests were performed by Graph Pad Prism 5.0 for
Windows (GraphPad Software, San Diego California, USA).

\section{Results}

Structure elucidation of ADHC-AXpn and DHC-Xpn

ADHC-AXpn was isolated as a white powder. The HR-FAB-MS showed a pseudo-molecular ion peak at $\mathrm{m} / \mathrm{z} 725.3887[\mathrm{M}+\mathrm{Na}]^{+}$(calc. 725.3893), which supported the molecular formula as being $\mathrm{C}_{39} \mathrm{H}_{58} \mathrm{O}_{11}$. The IR spectrum displayed the presence of hydroxyl groups $\left(3338 \mathrm{~cm}^{-1}\right)$ and a carbonyl group $\left(1730 \mathrm{~cm}^{-1}\right)$. The ${ }^{1} \mathrm{H}$ NMR spectrum (Table 1) showed signals of cyclopropane methylene groups at $\delta 0.43$ and $0.96 \mathrm{ppm}\left(\right.$ each ${ }^{1} \mathrm{H}, \mathrm{d}$, $J=4.0 \mathrm{~Hz}$ ), six methyl groups at $\delta 1.05,1.08,1.13,1.20$, 1.65 and $1.67 \mathrm{ppm}$; an aromatic proton at $\delta 4.82 \mathrm{ppm}$ $(\mathrm{d}, J=8.0 \mathrm{~Hz})$, and a series of overlapped signals, which suggested that ADHC-AXpn was a cycloartane-type triterpene glycoside [12]. The ${ }^{13} \mathrm{C}$-NMR (Table 1 ) displayed the diagnostic signals of two oxygen-bearing alkyl carbons at $\delta 87.0(\mathrm{C}-24)$ and $72.1 \mathrm{ppm}(\mathrm{C}-23)$, and an oxygen-bearing quaternary carbon at $\delta 113.0 \mathrm{ppm}$ (C-16), which implied that ADHC-AXpn was a cimigenol-type triterpene [13]. By fully comparing ${ }^{1} \mathrm{H}$ and ${ }^{13} \mathrm{C}$ NMR spectral data of ADHC-AXpn with those of the known component 25-O-acetyl-7,8-didehydrocimigenol3-O- $\beta$-D-xylopyranoside (25-AC) [12], the structure of ADHC-AXpn was similar to that of 25-AC, excepting an additional acetyl moiety. When the ${ }^{13} \mathrm{C}$-NMR spectrum of ADHC-AXpn was compared with that of 25-AC, the signals of $\mathrm{C}-1^{\prime}$ and $\mathrm{C}-3^{\prime}$ were seen to shift to higher field by 2.6 and $2.0 \mathrm{ppm}$, while the signal of $\mathrm{C}-2^{\prime}$ shifted to lower field. These chemical shift variations suggested an acetyl moiety was linked to the $\mathrm{C}-2^{\prime}$ of the xylose unit [12]. Locations of the two acetyl groups were directly confirmed by hetero-nuclear multiple bond correlation (HMBC) experiments (Fig. 2). Briefly, significant correlation was observed between $\mathrm{H}-2^{\prime}(\delta \mathrm{H} 5.56 \mathrm{ppm}$, dd, $J=7.5,8.1 \mathrm{~Hz}$ ) and the carbonyl signal at $\delta 170.3 \mathrm{ppm}$, which indicated an acetyl group was assignable to $\mathrm{C}-2^{\prime}$. The methyl signals at $\delta \mathrm{H} 1.65 \mathrm{ppm}(\mathrm{Me}-26) / \delta \mathrm{H} 1.67 \mathrm{ppm}$ (Me-27) also showed correlations with a quaternary carbon signal at $\delta \mathrm{C} 83.44 \mathrm{ppm}(\mathrm{C}-25)$, the methine carbon signal at $\delta \mathrm{C} 87.05 \mathrm{ppm}(\mathrm{C}-24)$, and the methyl carbon signals at $\delta C 21.58 \mathrm{ppm}(\mathrm{C}-27) / \delta \mathrm{C} 24.14 \mathrm{ppm}(\mathrm{C}-26)$, which indicated that another acetyl group was located at C-25. A complete ${ }^{1} \mathrm{H}$ and ${ }^{13} \mathrm{C}-\mathrm{NMR}$ spectral assignment of ADHC-AXpn was summarized in Tables 1 and 2.

Taken together, the structure of ADHC-AXpn was formulated as 25-O-acetyl-7,8-didehydrocimigenol-3$O-\beta$-D-(2-acetyl) xylopyranoside (Fig. 1). The known DHC-Xpn was determined as 7,8-didehydrocimigenol-3$O-\beta$-D-xylopyranoside by comparison of its spectral data with those reported in the literature [14]. 
Table $1{ }^{1} \mathrm{H}$ and ${ }^{13} \mathrm{C}$-NMR (400 MHz) data of ADHC-AXpn in pyridine- $d_{5}$

\begin{tabular}{|c|c|c|c|c|c|}
\hline Position & $\delta_{\mathrm{H}}(J=\mathrm{Hz})$ & $\delta_{c}$ & Position & $\delta_{\mathrm{H}}(J=\mathrm{Hz})$ & $\delta_{c}$ \\
\hline 1 & $\begin{array}{c}1.20 \mathrm{~m} \\
1.51 \mathrm{~m}\end{array}$ & 30.43 & 20 & $1.57 \mathrm{~m}$ & 23.67 \\
\hline 2 & $\begin{array}{c}1.87 \mathrm{~m} \\
2.26 \mathrm{~m}\end{array}$ & 29.67 & 21 & $0.89 d(6.5)$ & 19.95 \\
\hline 3 & $\begin{array}{l}3.38 \mathrm{dd}(4.0, \\
11.9)\end{array}$ & 88.61 & 22 & $0.94 \mathrm{~m}, 2.26 \mathrm{~m}$ & 38.07 \\
\hline 4 & & 40.37 & 23 & $4.60 \mathrm{~d}(9.3)$ & 72.17 \\
\hline 5 & $1.28 \mathrm{~m}$ & 42.78 & 24 & $4.11 \mathrm{~s}$ & 87.05 \\
\hline 6 & $\begin{array}{l}1.59 \mathrm{~m} \\
1.90 \mathrm{~m}\end{array}$ & 22.58 & 25 & - & 83.44 \\
\hline 7 & $\begin{array}{l}6.10 \mathrm{dd}(1.3, \\
7.5)\end{array}$ & 113.01 & 26 & $1.65 \mathrm{~s}$ & 24.14 \\
\hline 8 & - & 148.22 & 27 & $1.67 \mathrm{~s}$ & 21.58 \\
\hline 9 & - & 21.95 & 28 & $1.13 \mathrm{~s}$ & 18.74 \\
\hline 10 & - & 28.60 & 29 & $1.20 \mathrm{~s}$ & 25.79 \\
\hline 11 & $\begin{array}{l}1.13 \mathrm{~m} \\
2.04 \mathrm{~m}\end{array}$ & 25.71 & 30 & $1.05 \mathrm{~s}$ & 14.35 \\
\hline 12 & $\begin{array}{c}1.53 \mathrm{~m} \\
1.62 \mathrm{~m}\end{array}$ & 34.31 & $1^{\prime}$ & $4.84 \mathrm{~d}(7.5)$ & 104.81 \\
\hline 13 & - & 41.49 & $2^{\prime}$ & $\begin{array}{l}5.56 \mathrm{dd}(7.5, \\
8.1)\end{array}$ & 75.91 \\
\hline 14 & - & 50.74 & $3^{\prime}$ & $\begin{array}{l}4.13 \mathrm{dd}(8.1 \text {, } \\
8.1)\end{array}$ & 76.51 \\
\hline 15 & $4.27 \mathrm{~s}$ & 78.44 & $4^{\prime}$ & $4.21 \mathrm{~m}$ & 71.60 \\
\hline 16 & - & 114.4 & $5^{\prime}$ & $3.68 \mathrm{dd}$ & 67.41 \\
\hline 17 & $1.49 \mathrm{~d}(10.0)$ & 59.51 & & $\begin{array}{l}(10.0,11.0) \\
4.31 d d(5.0 \\
10.5)\end{array}$ & \\
\hline 18 & $1.08 \mathrm{~s}$ & 21.78 & $25-\mathrm{COCH}_{3}$ & $1.95 \mathrm{~s}$ & $170.4,21.5$ \\
\hline 19 & $\begin{array}{l}0.43 \mathrm{~d} \\
\quad(4.0), 0.96 \mathrm{~d} \\
(4.0)\end{array}$ & 28.35 & $2^{\prime}-\mathrm{COCH}_{3}$ & $2.14 \mathrm{~s}$ & $170.3,21.5$ \\
\hline
\end{tabular}

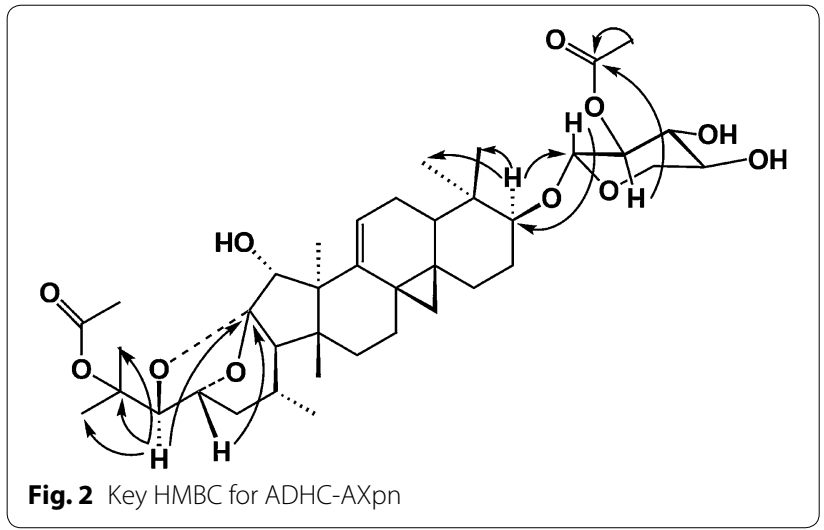

\section{Growth inhibition effects of ADHC-AXpn and DHC-Xpn on carcinoma cells}

The inhibitory effects of ADHC-AXpn and DHC-Xpn on the viability of various carcinoma cells were determined by MTT assay. ADHC-AXpn was much more potent than DHC-Xpn in decreasing the viability of the tested cells (MCF-7, HepG2/ADM, HepG2, HELA and PC3 cells) in both 24 and $48 \mathrm{~h}$ treatment periods apart from PC3 cells (Table 2). Among these cancer cells treated with ADHC-AXpn, MCF-7 cells appeared to be more sensitive to ADHC-AXpn than other cancer cells, as indicated by the $\mathrm{IC}_{50}$ values (Fig. 3a). As shown in Fig. 3b, the colony formation assay also confirmed that ADHCAXpn $(20,30$ or $35 \mu \mathrm{M})$ could inhibit proliferation of MCF-7 cells $(P=0.0078, P<0.001, P<0.0001)$. The $\mathrm{IC}_{50}$ values of ADHC-AXpn in human MCF10A mammary epithelial cells at $48 \mathrm{~h}$ were $78.63 \pm 3.26 \mu \mathrm{M}$, which was much higher than for cancer cell line MCF-7. These data indicated that ADHC-AXpn was selectively cytotoxic for cancer cells.

\section{ADHC-AXpn induces cell cycle arrest in MCF-7 cells}

We investigated the effect of ADHC-AXpn on the MCF-7 cell cycle by flow cytometry. Treating MCF-7 cells with ADHC-AXpn for $24 \mathrm{~h}$ induced a $\mathrm{G}_{2} / \mathrm{M}$ arrest (Fig. 4a). The percentage of cells in subG $\mathrm{G}_{1}$ phase increased when ADHC-AXpn exposure was extended to $48 \mathrm{~h}$. To explore the mechanism of ADHC-AXpn-induced $G_{2} / M$ arrest, we investigated its effects on $\mathrm{G}_{2} / \mathrm{M}$ regulatory proteins. Western blotting showed ADHC-AXpn caused a timeand dose-dependent decrease in cyclin B1 (Fig. 4b). ADHC-AXpn decreased cyclin-dependent kinase 1 (CDK1), which regulates the cell cycle by forming the CDK-cyclin complex, and phospho-CDK1 $\left(\mathrm{Thr}^{161}\right)$. ADHC-AXpn arrests the cell cycle in $G_{2} / M$ phase by decreasing expression of cyclin B1, CDK1 and phosphoCDK1 $\left(\mathrm{Thr}^{161}\right)$.

\section{Induction of apoptosis by ADHC-AXpn in MCF-7 cells}

Changes of cellular morphology were examined by fluorescent microscopy analysis (Fig. 5a). After treatment with different concentrations of ADHC-AXpn (20, 30 or $35 \mu \mathrm{M}$ ) for $48 \mathrm{~h}$, cells stained with Hoechst 33258 showed apoptotic features, such as cytoplasmic shrinkage and condensation of nuclear chromatin. Consistently, PI/Annexin V double staining analysis (Fig. 5b) showed that treatment with ADHC-AXpn (30 or $35 \mu \mathrm{M})$ for $48 \mathrm{~h}$ led to significantly increased cell percentages in early and late apoptotic phases $(P=0.0094$ and $P=0.0042$ vs. control, respectively). Cleavage of PARP was also seen in ADHC-AXpn-treated MCF-7 cells (Fig. 5c).

\section{Activation of mitochondrial apoptotic pathway and inhibition of Akt phosphorylation}

Changes of MMP were measured by a fluorescent dye (JC-1) to further investigate the apoptotic pathway. MCF-7 cells treated with ADHC-AXpn (20, 30 or $35 \mu \mathrm{M}$ ) for $24 \mathrm{~h}$ showed a gradual decrease in the 
Table 2 The inhibitory effects of ADHC-AXpn and DHC-Xpn on the viability of human carcinoma cells

\begin{tabular}{|c|c|c|c|c|c|}
\hline & \multicolumn{2}{|c|}{ ADHC-AXpn $\left(\mathrm{IC}_{50}, \mu \mathrm{M}\right)$} & \multicolumn{2}{|c|}{ DHC-Xpn $\left(I C_{50}, \mu M\right)$} & \multirow{2}{*}{$\begin{array}{l}\text { Dox } \\
48 \mathrm{~h}\end{array}$} \\
\hline & $24 \mathrm{~h}$ & $48 h$ & $24 \mathrm{~h}$ & $48 h$ & \\
\hline MCF-7 & $30.32 \pm 0.79$ & $27.81 \pm 1.29$ & $>50$ & $42.14 \pm 4.63$ & $4.07 \pm 1.33$ \\
\hline HepG2 & $40.73 \pm 1.46$ & $35.65 \pm 1.17$ & $>50$ & $42.51 \pm 2.57$ & $3.80 \pm 0.95$ \\
\hline HepG2/ADM & $33.66 \pm 3.64$ & $29.61 \pm 0.26$ & $>50$ & $>50$ & $143.47 \pm 4.76$ \\
\hline HeLa & $41.25 \pm 0.23$ & $35.73 \pm 2.15$ & $>50$ & $>50$ & $4.62 \pm 1.37$ \\
\hline PC3 & $>50$ & $>50$ & $>50$ & $>50$ & $5.52 \pm 1.19$ \\
\hline
\end{tabular}

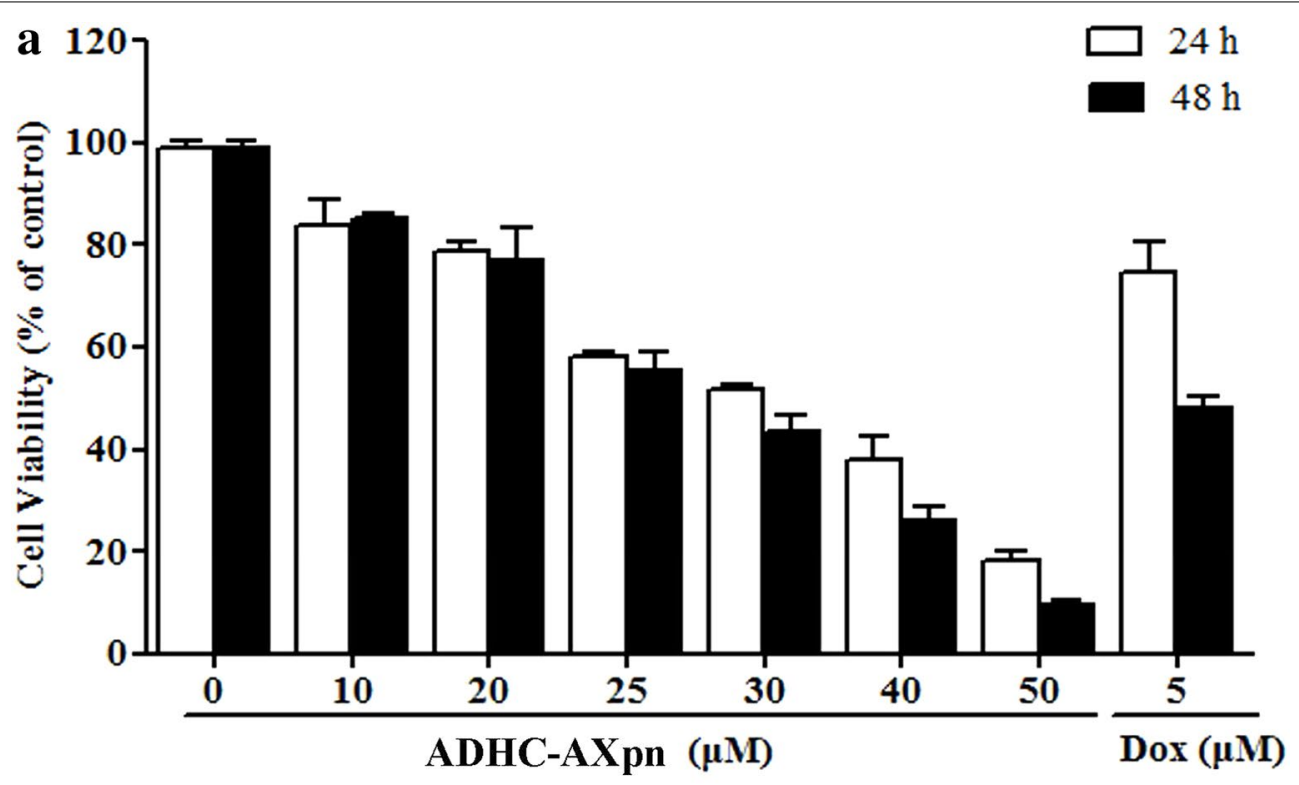

b
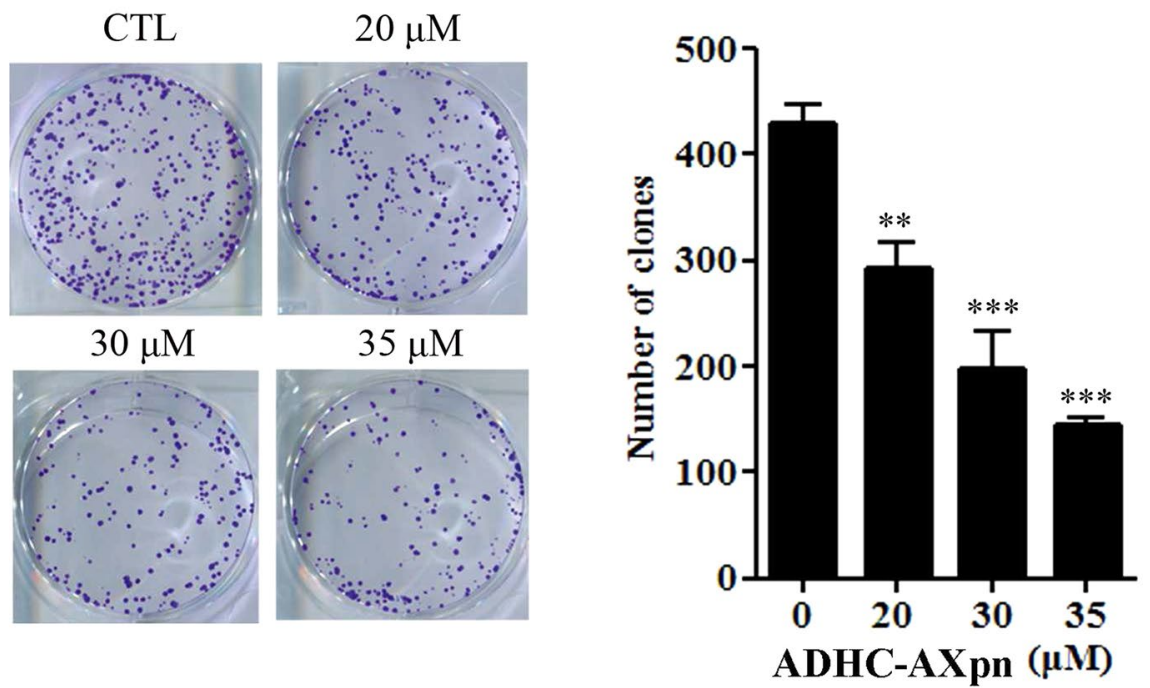

Fig. 3 Growth inhibitory activity of ADHC-AXpn in MCF-7 cells. a Cells were treated with increasing concentrations of ADHC-AXpn (10 to $50 \mu \mathrm{MM})$ for 24 and $48 \mathrm{~h}$; cell survival was then assessed by MTT assay. Doxorubicin (Dox) exposure at $5 \mu \mathrm{M}$ was used as a positive control. b After exposure to ADHC-AXpn at concentrations of 20, 30 or $35 \mu \mathrm{M}$, cells were seeded onto 6-well plates (600 cells/well) for assessing colony formation. Data are expressed as mean \pm SD of three independent experiments with ${ }^{* *} P=0.0078$; ${ }^{* *} P<0.001$ 


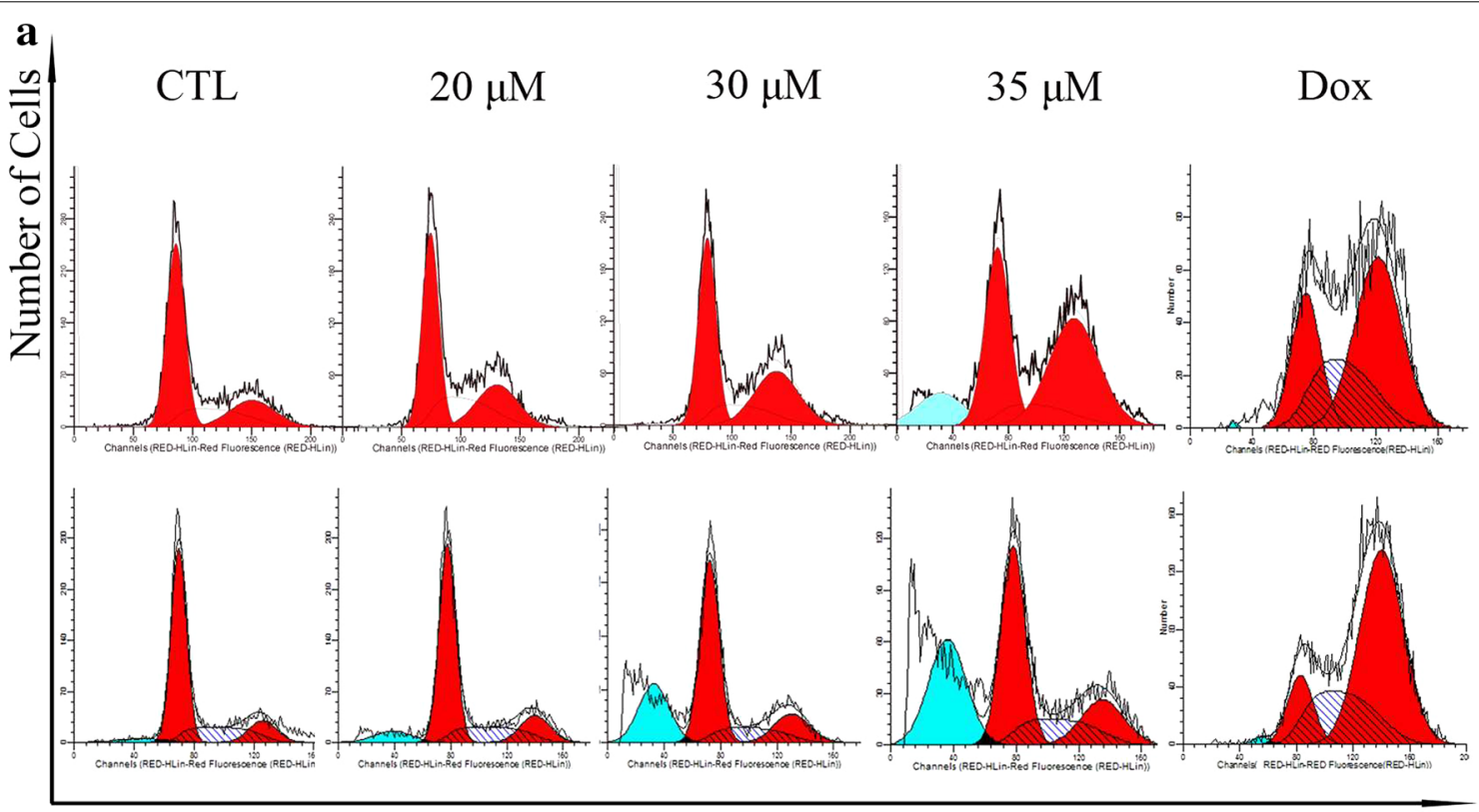

DNA Content

b

$48 \mathrm{~h}$

$35 \mu \mathrm{M}$

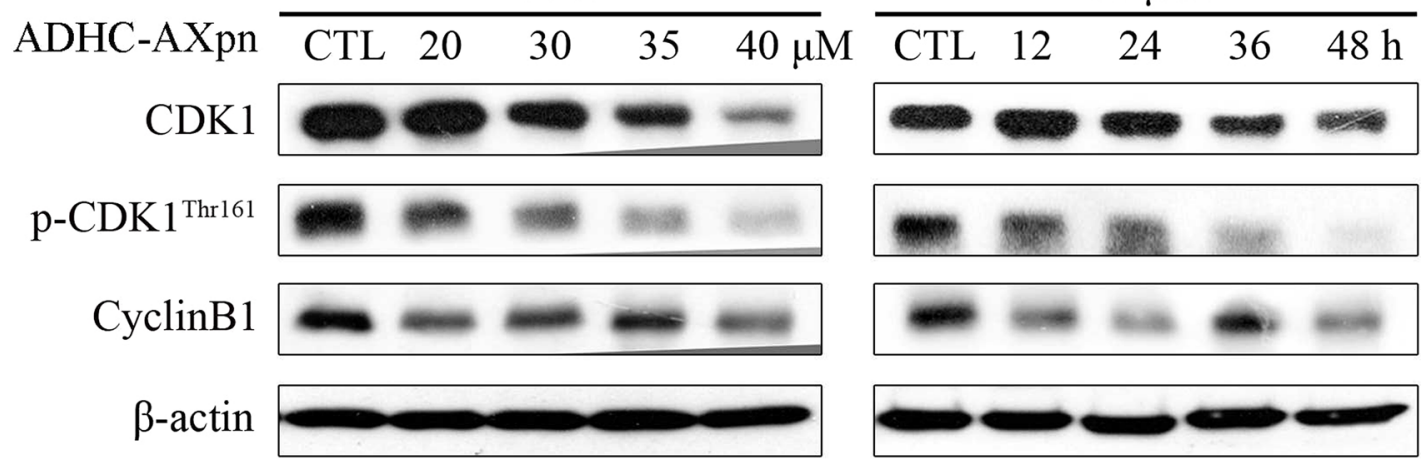

Fig. 4 Cell-cycle arrest induced by ADHC-AXpn in MCF-7 cells. a Cell cycle profiles of MCF-7 cells after treatment with ADHC-AXpn for 24 or 48 h. Cells exposed to indicated concentrations of ADHC-AXpn were collected, fixed with $75 \%$ ethanol overnight, and stained with PI for 30 min; cellcycle profiles were then determined by flow cytometry. Doxorubicin (dox) exposure at $5 \mu \mathrm{M}$ was used as a positive control. b Changes in cell-cycle regulator protein expression after exposure to ADHC-AXpn in MCF-7 cells. After treatment with ADHC-AXpn, total cell lysates were immunoblotted to detect CDK1, p-CDK1 $\left(\right.$ Thr $\left.^{161}\right)$ and cyclin B1 expression levels, using specific antibodies. $\beta$-actin served as a loading control

percentage of cells with high MMP from 94.1 (control) to $68.7 \%, 63.0$ and $55.9 \%$, respectively (Fig. 6a). We examined expression levels of pro-apoptotic protein Bax and anti-apoptotic protein Bcl-2. Western blot analysis showed that ADHC-AXpn treatment down-regulated Bcl-2 and clearly up-regulated Bax (Fig. 6b). The precursor form of caspase- 9 was decreased, whereas expression of cleaved caspase- 9 was increased. ADHCAXpn exposure remarkably decreased p-Akt $\left(\mathrm{Thr}^{308}\right.$ and $\mathrm{Ser}^{473}$ ), although total Akt showed no visible change.

\section{Raf/MEK/ERK pathway inhibition by ADHC-AXpn in MCF-7} cells

The Raf/MEK/ERK pathway is beneficial for survival of MCF-7 cells, and blockage of this pathway can trigger apoptosis [15]. To investigate whether the Raf/MEK/ ERK pathway affects ADHC-AXpn-induced apoptosis, we assessed expression levels of p-ERK1/2 and p-c-Raf. Compared with the control group, ADHC-AXpn treatment decreased phosphorylation of ERK1/2 in both timeand dose-dependent manners (Fig. 6c). The upstream 

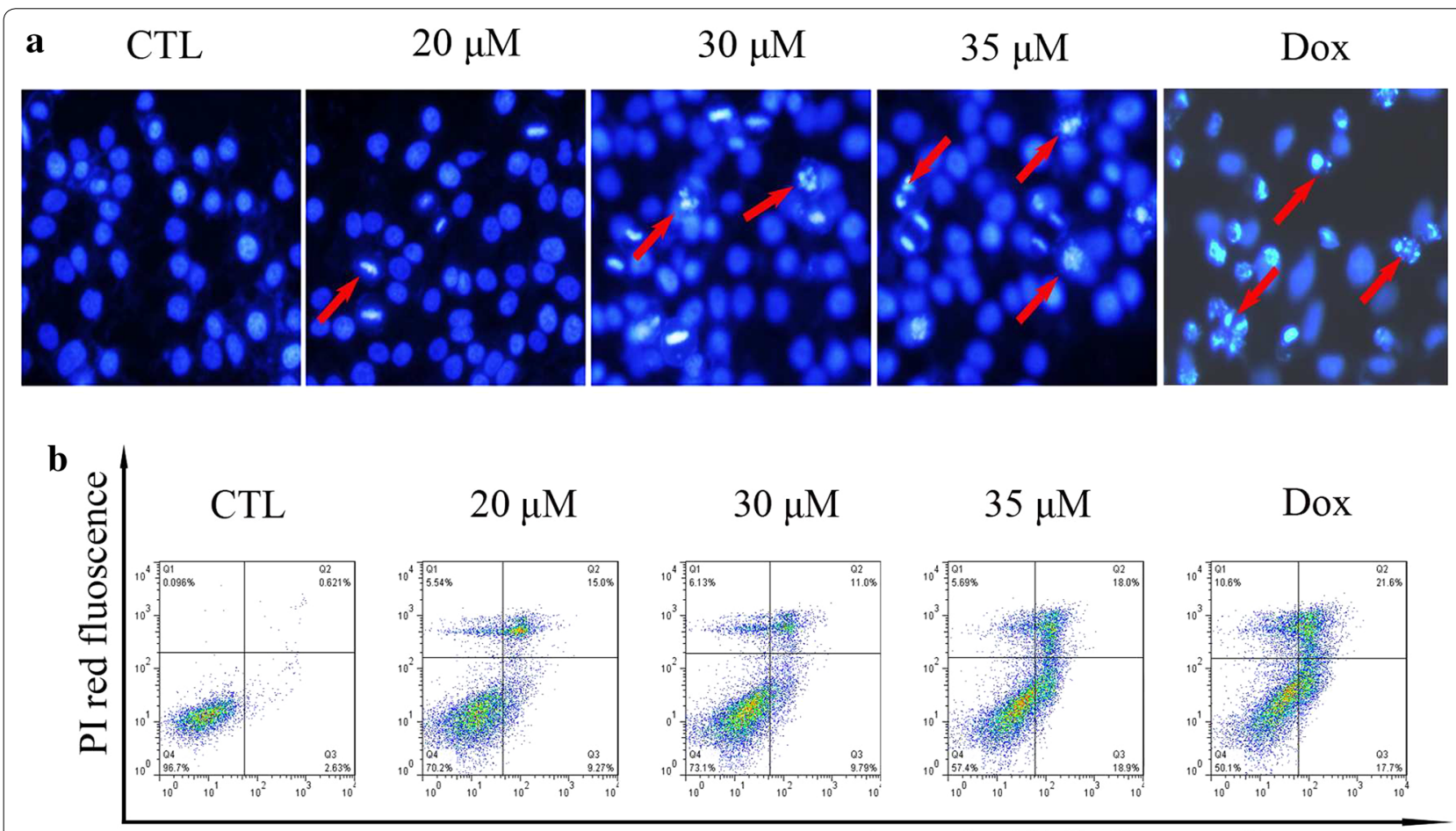

Annexin-V FITC green fluoscence

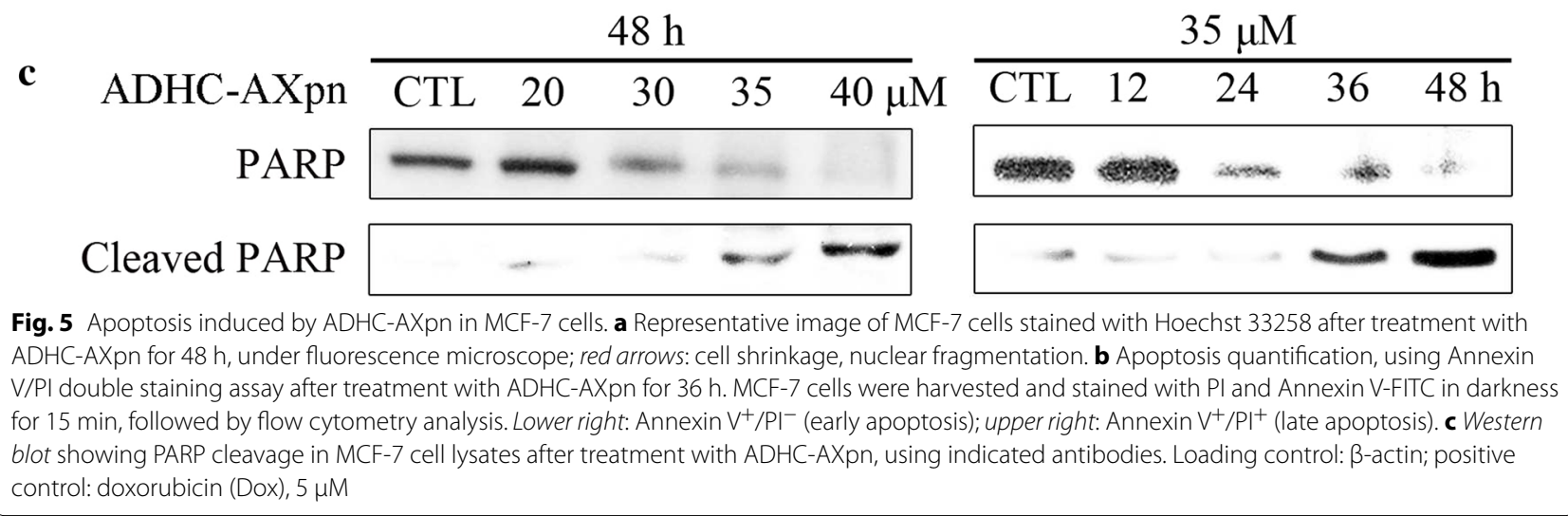

regulator of ERK1/2, p-c-Raf, was also down-regulated after exposure to ADHC-AXpn.

\section{Discussion}

In the present study, a novel cycloartane triterpenoid, ADHC-AXpn and the known DHC-Xpn were isolated and identified from C. foetia. The cytotoxic effects of these two isolated components on human cancer cells MCF-7, HepG2, HepG2/ADM, HeLa, PC3 and normal human mammary epithelial cells MCF10A were assessed by MTT assay and colony formation assay. ADHC-AXpn, which possesses acetyl groups at C-25 and $\mathrm{C}-2^{\prime}$ in its sugar groups, was more cytotoxic toward all tested cell lines than was DHC-Xpn, which bears hydroxyl groups at $\mathrm{C}-25$ and $\mathrm{C}-2^{\prime}$ in its sugar group. Addition of a hydrophobic group (such as acetyl or halogen) linked to C-25 or other positions remarkably increased cytotoxic activity, which were consistent with a previous report on the structure-activity relationship of cycloartane triterpenoids in other cells [4]. The $\mathrm{IC}_{50}$ value of $\mathrm{ADHC}-\mathrm{AXpn}$ for normal human mammary epithelial cells MCF10A was higher than those for cancer cells.

Activation of the apoptotic pathway in tumor cells is a major protective mechanism against the development and progression of cancer [16]. On the basis 

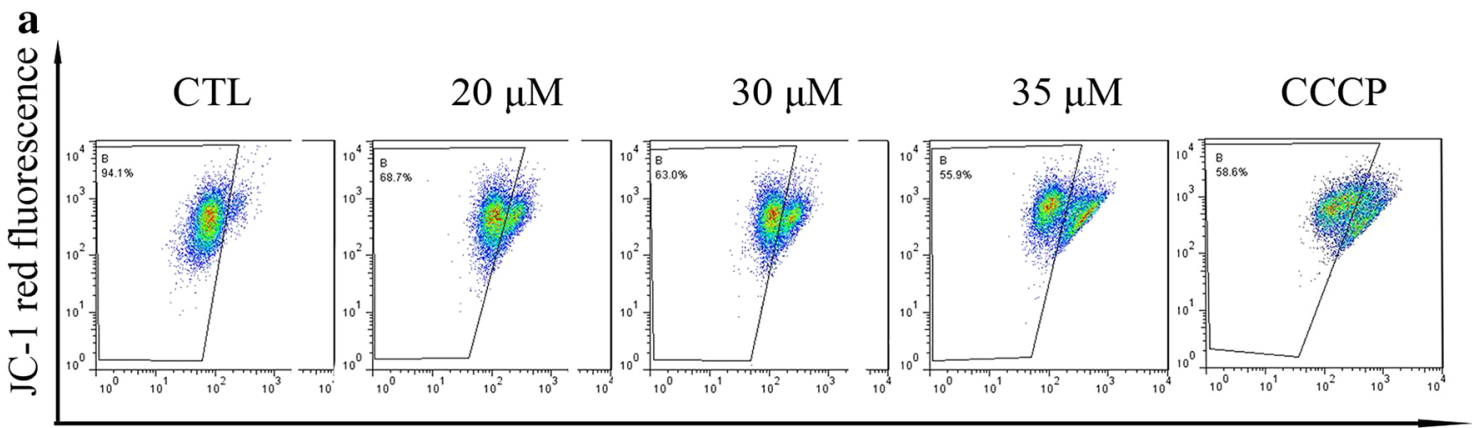

JC-1 green fluorescence

b
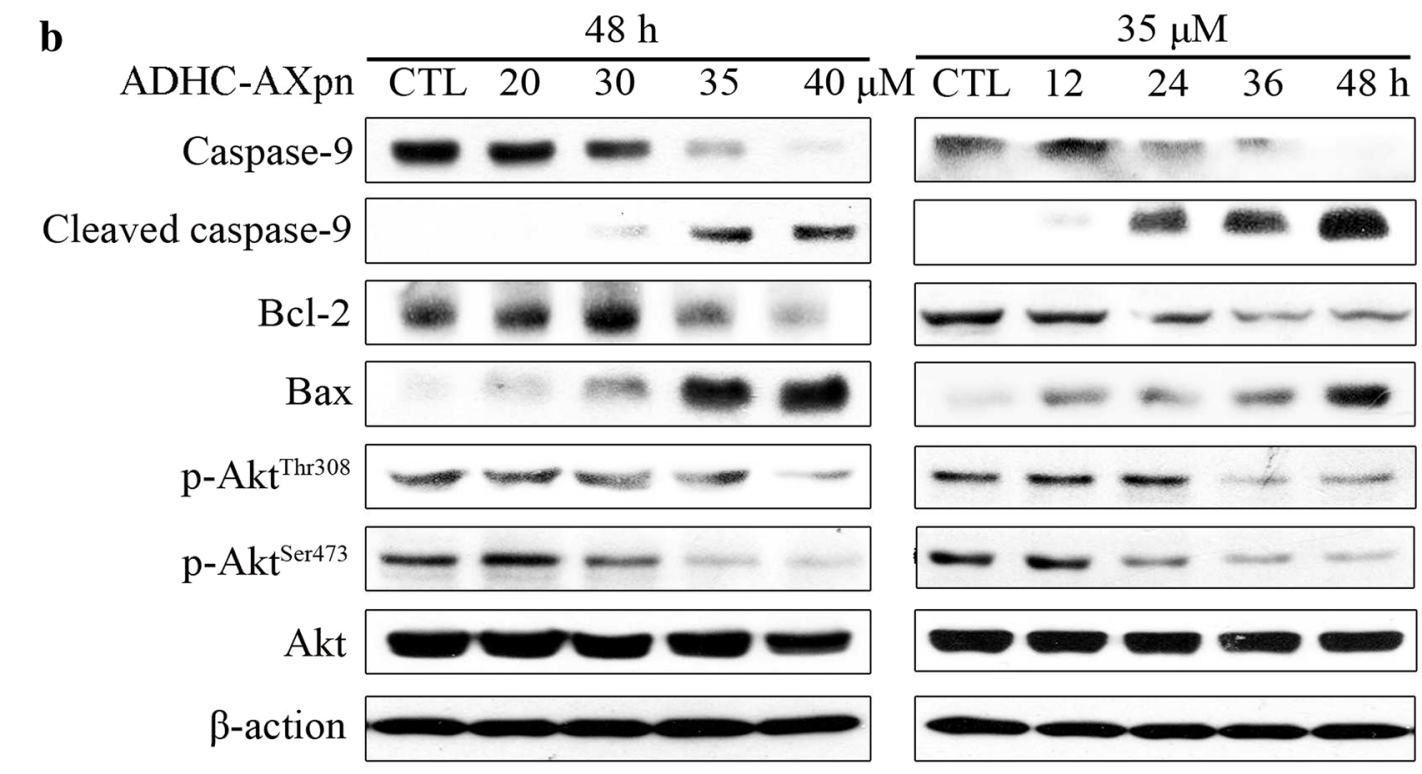

c
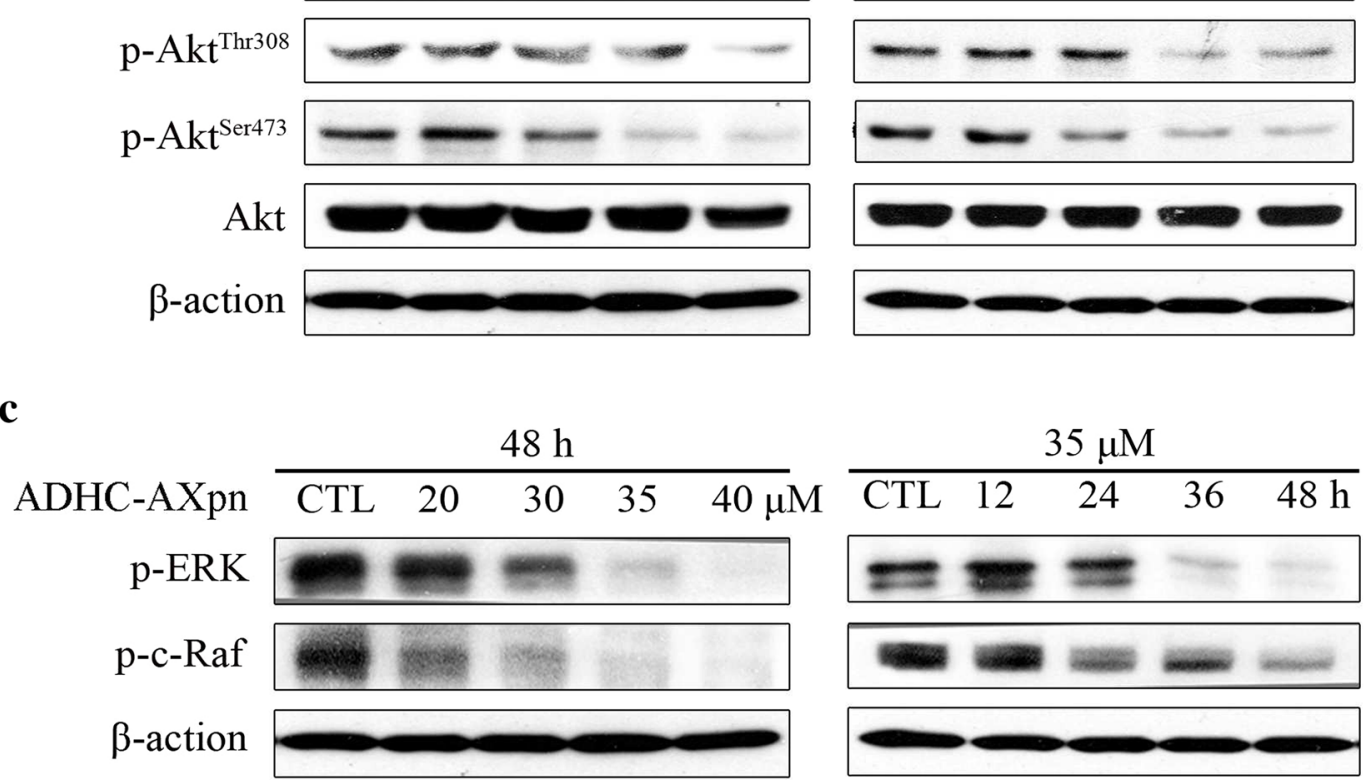

Fig. 6 Effect of ADHC-AXpn on mitochondrial function and Raf/MEK/ERK signaling pathway in MCF-7 cells. a Flow cytometry shows mitochondrial membrane depolarization induced by treatment with indicated concentrations of ADHC-AXpn for $24 \mathrm{~h}$; detached cells were stained with JC-1; generic mitochondrial membrane depolarizer CCCP $(20 \mu \mathrm{M})$, used as positive control, showed an expected decrease in red fluorescence. b Western blot shows caspase activation and changes in expression levels of $\mathrm{BCl}-2$ family proteins and Akt proteins in MCF-7 cells after treatment with ADHCAXpn, using specific antibodies against caspase-9, cleaved caspase-9, Bcl-2 and Bax, Akt and p-Akt (Thr ${ }^{308}$ and Ser ${ }^{473}$ ), respectively. c Western blot shows inhibition of Raf/MEK/ERK signaling pathway related proteins in MCF-7 cells after treatment with ADHC-AXpn, using the indicated antibodies; loading control: $\beta$-actin

of the detected cytotoxic effects of ADHC-AXpn and DHC-Xpn on MCF-7, HepG2, HepG2/ADM, HeLa and PC3 cells (Table 2), further studies were performed to explore the mechanism of ADHCAXpn-induced cell death in MCF-7 cells. To our knowledge, our study was the first one to demonstrate 
that ADHC-AXpn could induce MCF-7 cell death via apoptosis, accompanied with stereotypical apoptotic features that include cell shrinkage, phosphatidylserine (PS) externalization and PARP cleavage. ADHCAXpn inhibited cyclin B1 and CDK1, and thereby led to clear $\mathrm{G}_{2} / \mathrm{M}$ arrest.

Apoptosis has two major pathways: the cell death receptor-mediated apoptotic pathway and the mitochondrial-mediated apoptotic pathway [17]. The latter is also referred to as the intrinsic apoptosis pathway, and it is involved in the caspase-dependent apoptotic pathway $[18,19]$. Bcl-2 family proteins are major regulators of the mitochondrial pathway; $\mathrm{Bcl}-2$ is a major anti-apoptosis protein, integrated in the mitochondrial membrane, and Bax is inactive in the cytosol or loosely attached to intracellular membranes as a monomer $[20,21]$. The over-expression of Bax and lowerexpression of $\mathrm{Bcl}-2$ induce the MMP collapse and a subsequent cascade activation of caspases through homologous dimerization, and eventually lead to apoptosis. Four isolated cycloartane triterpenoids from Cimicifuga yunnanensis, another species of Cimicifuga genus, 25-O-acetylcimigenol-3-O- $\beta$-D-xylopyranoside, 25 -chlorodeoxycimigenol-3-O- $\beta$-D-xylopyranoside, $25-O$-acetylcimigenol-3-O- $\alpha-\mathrm{L}$-arabinopyranoside and 23-O-acetylcimigenol-3-O- $\beta$-D-xylopyranoside increased expression of p53 and Bax, resulting in mitochondriamediated apoptosis [6]. Our results showed similar phenomena, including changes in Bcl-2 and Bax levels, and decreased MMP and caspase-9 activation (Fig. 6a, b), implying that mitochondrial dysfunction was involved in ADHC-AXpn-induced apoptosis in MCF-7 cells. In addition, decreased Akt phosphorylation might be involved in ADHC-AXpn-induced apoptosis, as Akt activation protects cells from apoptosis via inhibiting pro-apoptotic molecues [22].

The Raf/MEK/ERK pathway can transduce signals that originate from growth factor receptors to transcription factors, thus controlling cell survival and proliferation [15]. Raf, mediated cell cycle progression by regulating cell-cycle associated proteins such as Cdks, cyclins and p21 ${ }^{\text {Cip1 }}[23,24]$. The Raf/MEK/ERK pathway also affects apoptosis progression. Raf can induce transcription of anti-apoptotic genes such as $B c l$-2, and activation of the Raf/MEK/ERK pathway, leading to phosphorylation and inactivation of the pro-apoptotic protein Bad [25-27]. ERK1/2 is required for survival signaling and ERK1/2 inhibition is a crucial part of the apoptotic mechanisms of various stimuli [28]. Our present studies on the regulatory effects of ADHC-AXpn on cyclin B1, CDK1, caspase-9, Bax and Bcl-2, suggested that the Raf/MEK/ERK pathway might be involved in ADHC-AXpn-induced apoptosis.

\section{Conclusions}

ADHC-AXpn significantly suppressed the growth of MCF-7 cells, induced mitochondrial apoptosis and cellcycle arrest, and inhibited Raf/MEK/ERK signaling pathway and Akt phosphorylation.

\section{Abbreviations}

Sheng ma: the rhizome of Cimicifuga foetida $\mathrm{L} ; \mathrm{CM}$ : Chinese medicine ADHC-AXpn: 25-O-acetyl-7,8-didehydrocimigenol-3-O- $\beta$-D-(2-acetyl) xylopyranoside; DHC-Xpn: 7,8-didehydrocimigenol-3-O- $\beta$-D-xylopyranoside; 25-AC: 25-O-acetyl-7,8-didehydrocimigenol-3-O- $\beta$-D-xylopyranoside; CATP: cycloartane triterpenoid; IR: infrared spectra; HR-FAB-MS: high resolution fast atom bombardment mass spectra; NMR: nuclear magnetic resonance; HMBC: hetero-nuclear multiple bond correlation; CCG: column chromatography; TLC: thin layer chromatography; MTT: 3-(4, 5)-Dimethylthiazol-2-yl)-2, 5-diphenyl tetrazolium bromide; Pl: propidium iodide; Dox: doxorubicin; JC-1: 5, 5', 6, 6'-tetrachloro-1, 1', 3, 3'-tetraethyl benzimidazolyl-carbocyanine iodide; DMSO: dimethyl sulfoxide; FBS: fetal bovine serum; PBS: phosphate buffered saline; PI: peromide iodine; P/S: penicillin-streptomycin.

\section{Authors' contributions}

SBC and DMZ designed the study. BBL isolated the tested compounds. WCY performed the structure elucidation of tested compounds. HYS, JYH and LJX performed the biological experiments. HYS and COC performed the data analysis and wrote the manuscript. DKWM and SWC revised the manuscript. All authors read and approved the final manuscript.

\section{Author details}

${ }^{1}$ Institute of Medicinal Plant Development, Chinese Academy of Medical Sciences and Peking Union Medical College, Beijing, China. ${ }^{2}$ State Key Laboratory of Chinese Medicine and Molecular Pharmacology, Hong Kong Polytechnic University, Hong Kong, China. ${ }^{3}$ College of Pharmacy, Jinan University, Guangzhou, China.

\section{Acknowledgements}

This work was supported by the National Natural Science Foundation of China (No. 81373953; 81303203) and Shenzhen Basic Research Program, China (JCYJ20120618173411244), and was part of the work of the Hong Kong Chinese Material Medica Standard Project.

\section{Competing interests}

The authors declare that they have no competing interests.

Received: 14 October 2014 Accepted: 9 December 2015 Published online: 11 January 2016

\section{References}

1. Man SL, Gao WY, Wei CL, Liu CX. Anticancer drugs from traditional toxic Chinese medicines. Phytother Res. 2012;26:1449-65.

2. Dinda B, Debnath S, Mohanta BC, Harigaya Y. Naturally occurring triterpenoid saponins. Chem Biodivers. 2010;7:2327-580

3. Tian Z, Sun Y, Xiao PG, Wu E: Recent advances in natural bioactive cycloartane triterpenoids. In: Awaad AS, Kaushik G, Govil JN, editors. Mechanism and action of phytoconstituents - recent progress in medicinal plants, vol. 31. New Delhi: Studium Press (India) Pvt. Ltd.; 2011. p. 49-63.

4. Tian Z, Yang MS, Huang F, Li K, Si JY, Shi L, Chen SB, Xiao PG. Cytotoxicity of three cycloartane triterpenoids from Cimicifuga dahurica. Cancer Lett. 2005;226:65-75.

5. Tian Z, Zhou L, Huang F, Chen SB, Yang JS, Wu E, Xiao PG, Yang MS. Anti-cancer activity and mechanisms of 25-anhydrocimigenol-3-O- $\beta$-Dxylopyranoside isolated from Souliea vaginata on hepatomas. Anti-Cancer Drug. 2006;17:545-51.

6. Fang ZZ, Nian Y, Li W, Wu JJ, Ge GB, Dong PP, Zhang YY, Qiu MH, Liu L, Yang L. Cycloartane triterpenoids from Cimicifuga yunnanensis induce apoptosis of breast cancer cells (MCF7) via p53-dependent mitochondrial signaling pathway. Phytother Res. 2011;25:17-24. 
7. Nian Y, Wang HY, Zhou L, Su J, Li Y, Qiu MH. Cytotoxic cycloartane triterpenes of the traditional Chinese medicine "shengma" (Cimicifuga dahurica). Planta Med. 2013;79:60-9.

8. China Pharmacopoeia Committee. Pharmacopoeia of the People's Republic of China, vol. 1. Beijing: Chinese medicine and technology publishing house; 2015. p. 73-4.

9. Nian Y, Zhang YL, Chen JC, Lu L, Qiu MH, Qing C. Cytotoxic chemical constituents from the roots of Cimicifuga foetida. J Nat Prod. 2010;73:93-8.

10. Nian Y, Zhang XM, Li Y, Wang YY, Chen JC, Lu L, Zhou L, Qiu MH. Cycloartane triterpenoids from the aerial parts of Cimicifuga foetida Linnaeus. Phytochemistry. 2011;72:1473-81.

11. Fu JJ, Ju DH, Xie YM. Low cell density induced Epithelial-Mesenchymal transition in MCF-10A cell is regulated by proteasome activity. J Oncobiomarkers. 2013;1:4-8

12. Kusano A, Takahira M. ShibanoM, Miyase T, Kusano G: Studies on the constituents of Cimicifuga species. XXVI. Twelve new cyclolanostanol glycosides from the underground parts of Cimicifuga simplex Wormsk. Chem Pharm Bull. 1999;47:511-6.

13. Nian Y, Wang HY, Su J, Zhou L, Feng G, Li Y, Qiu MH. Cytotoxic cycloartane triterpenes from the roots of Cimicifuga heracleifolia. Tetrahedron 2012;68:6521-7

14. Zhang QW, Ye WC, Zhao SX, Che ZT. Studies on chemical constituents of Cimicifuga dahurica. Chin Trad Herb Drug. 2002;33:683-5.

15. Chang F, Steelman LS, Shelton JG, Lee JT, Navolanic PM, Blalock WL, Franklin R, McCubrey JA. Regulation of cell cycle progression and apoptosis by the Ras/Raf/MEK/ERK pathway (review). Int J Oncol. 2003;22:469-80.

16. Cheng L, Wang X, Zhang J, Zhang SB, Zheng SQ, Zheng J. Targeting apoptosis signaling pathways in cancer therapy. Chin J Pathol. 2009;38:639-42.

17. Soldatenkov VA, Smulson M. Poly (ADP-ribose) polymerase in DNA damage-response pathway: implications for radiation oncology. Int J Cancer. 2000;90:59-67.

18. Huang WW, Chiu YJ, Fan MJ, Lu HF, Yeh HF, Li KH, Chen PY, Chung JG, Yang JS. Kaempferol induced apoptosis via endoplasmic reticulum stress and mitochondria-dependent pathway in human osteosarcoma U-2 OS cells. Mol Nutr Food Res. 2010;54:1585-95.

19. Polster BM, Fiskum G. Mitochondrial mechanisms of neural cell apoptosis. J Neurochem. 2004;90:1281-9.
20. Kowaltowski AJ, Vercesi AE, Fiskum G. Bcl-2 prevents mitochondrial permeability transition and cytochrome $c$ release via maintenance of reduced pyridine nucleotides. Cell Death Differ. 2000;7:903-10.

21. Reed JC. Proapoptotic multidomain BCl-2/Bax-family proteins: mechanisms, physiological roles, and therapeutic opportunities. Cell Death Differ. 2006;13:1378-86

22. Hennessy BT, Smith DL, Ram PT, Lu Y, Mills GB. Exploiting the PI3 K AKT pathway for cancer drug discovery. Nat Rev Drug Discov. 2005;4:988-1004.

23. Chang F, Steelman LS, McCubrey JA. Raf-induced cell cycle progression in human TF-1 hematopoietic cells. Cell Cycle. 2002;1:220-6.

24. Lee JTJ, McCubrey JA. The Raf/MEK/ERK signal transduction cascade as a target for chemotherapeutic intervention in leukemia. Leukemia. 2002;16:486-507.

25. Kauffmann-Zeh A, Rodriguez-Viciana P, Ulrich E, Gilbert C, Coffer P, Downward J, Evan G. Suppression of c-Myc-induced apoptosis by Ras signalling through PI(3)K and PKB. Nature. 1997;385:544-8.

26. Majewski M, Nieborowska-Skorska M, Salomoni P, Slupianek A, Reiss K, Trotta R, Calabretta B, Skorski T. Activation of mitochondrial Raf-1 is involved in the antiapoptotic effects of Akt. Cancer Res. 1999;59:2815-9.

27. Blagosklonny MV, Demidenko ZN, Fojo T. Inhibition of transcription results in accumulation of Wt p53 followed by delayed outburst of p53-inducible proteins: p53 as a sensor of transcriptional integrity. Cell Cycle. 2002;1:67-74

28. Yuan L, Wang J, Xiao H, Wu W, Wang Y, Liu X. MAPK signaling pathways regulate mitochondrial-mediated apoptosis induced by isoorientin in human hepatoblastoma cancer cells. Food Chem Toxicol. 2013;53:62-8.

\section{Submit your next manuscript to BioMed Central and we will help you at every step:}

- We accept pre-submission inquiries

- Our selector tool helps you to find the most relevant journal

- We provide round the clock customer support

- Convenient online submission

- Thorough peer review

- Inclusion in PubMed and all major indexing services

- Maximum visibility for your research

Submit your manuscript at www.biomedcentral.com/submit

O) Biomed Central 